\title{
A Conversation with Iain Cheeseman
}

\author{
INTERVIEWER: LARA SZEWCZAK \\ Scientific Editor, Cell
}

\begin{abstract}
Iain Cheeseman is an Associate Professor of Biology at the Massachusetts Institute of Technology, and a member of the Whitehead Institute for Biomedical Research, Cambridge, Massachusetts.
\end{abstract}

Lara Szewczak: You've worked a lot on the kinetochore, which is this massive, dynamic assembly of proteins that helps anchor chromosomes to microtubules, to allow chromosome segregation. What got you interested in studying that complex?

Iain Cheeseman: When I was a grad student, I'd always found the cell cycle and cell division to be interesting. I joined Georjana Barnes and Dave Drubin's lab in 1997. At that point, I don't think I'd even heard of what the kinetochore was as a thing, and I had a project where I was going to work on this microtubule-associated protein in budding yeast. About a year or two into that, I started to realize that this protein was probably doing something else. This was a protein called Dam1 and I realized that in addition to holding on to a microtubule, it was at this structure called the kinetochore.

At that point, I kind of just fell in love with that structure. It was everything I wanted to try to understand about a cell. It's a very physical structure. There're a lot of proteins there. It's a very mechanical structure; it has to do stuff. There's a business end of what it has to achieve, and it's a highly controlled structure. You need to coordinate that with the cell and the cell cycle and ensure that you're not generating errors. I really loved that set of challenges. You have this machine: You have to build it, and have it physically do stuff, and you have to control it. When I started in '97, there were maybe 12 proteins that we knew about that were kinetochore components, so this was quite early days. It was just beautiful to see this expanding list of molecular complexity and to really understand how this process works. I fell in love with this Dam1 complex and the entire kinetochore and have never really stopped.

Lara Szewczak: You said there were 12 proteins when you started. How many are there now?

Iain Cheeseman: In human cells, I would say $~ 110$, but it varies in different organisms. The Dam1 complex is a protein that is this beautiful ring-like machine that holds onto the microtubule and carries a chromosome with it. I loved studying that, but one of my advisors, Dave Drubin, pretty much every week would walk into the lab and say, "Okay, so have you found the human homolog yet?" I felt like I was really bad at BLAST searches for many years, but it turns out it actually doesn't exist, so there certainly are differences between organisms. Some things are true in fungi, but slightly different in human cells. Then I transitioned to Arshad Desai's lab, where I focused on C. elegans kinetochores, which are holocentric; they occupy the entire chromosome. They're very similar to yeast and very similar to human cells, yet also different in other ways, in terms of that machine. But probably, the largest number of proteins we know is in human cells. I think you can argue a bit about, "What is a kinetochore component?" or "What is a protein that is at that site?" but I think, as I would define it, $\sim 110$.

Lara Szewczak: What makes something a kinetochore component as opposed to "just in the vicinity"?

Iain Cheeseman: The way I would define that is the connectivity between the chromosomal DNA and a microtubule polymer. You have to hold on to the nucleic acid, the chromosome. You have to be able to help mediate its segregation. You have to hold on to the microtubule. The things that are localized to the site that are playing a role in those interactions and holding that entire structure together, I would put in that category. But it's a really complex part of the DNA as well, so there's going to be heterochromatin there, and other specific things that participate in that way. I probably wouldn't define those as kinetochore components.

Lara Szewczak: Can give a bit of an overview of your present work?

Iain Cheeseman: I love what this molecular machine is, and the complexity of how you build this, and assemble it, and drive things. But I also loved when I was working in budding yeasts, where you could do clean and clear genetic experiments. So I transitioned to C. elegans, and then about halfway through in Arshad's lab, I started working on human cells. About $95 \%$ of our lab's work now is in human cell culture.

(C) 2017 Cheeseman. This article is distributed under the terms of the Creative Commons Attribution-NonCommercial License, which permits reuse and redistribution, except for commercial purposes, provided that the original author and source are credited. 
Human cells are gorgeous. They're beautiful. They're big. You can really nicely see the spindle and the kinetochore structure. But it was really hard to do a yeast-like experiment there, and I've always kind of been jealous about that: the clarity and clearness by which you can create a replacement, or really ask what a protein in doing. I think the CRISPR-based approaches are really revolutionizing how we can think about doing that sort of experiment. We still cannot backcross human cells and do some of the beautiful kind of genetics that you'd want, but I think a lot of things are accessible there, in a way that wasn't even a year or two ago. We've been exploiting that approach, and it's caused us to reimagine a lot of our expectations.

For example, take those 110 proteins. The kinetochore is critical for what it means to be a cell. Every time you make two cells, you have to distribute your chromosomes. You have to do that process correctly. You have to make sure that you not only physically achieve that, but you do that with high fidelity. That should be an essential process, right? For a cell to continue to survive and duplicate, the kinetochore should be essential. Yet in budding yeast, out of, say, 65 yeast kinetochore proteins, there's probably about 25 or 30 that you can eliminate, and that yeast cell will apparently grow fine.

We know of a lot of human kinetochore proteins, but it would be very hard to say which of those are actually essential. They're important, but could you get rid of them and have the cell still survive? RNAi was a wonderful way to be able to do functional experiments, but that really simple thing-“'Is this thing essential or not?"- is not something that we could access. That's really been transformed by the ability to go in and clearly and carefully knock stuff out with CRISPR. We've been exploiting that strategy to go through things and a lot of those things have conformed to our expectations, but a lot of those things have been a surprise. That simple metric - "Is this essential?"-really changes the way you see a process.

There's a signaling pathway called the spindle assembly checkpoint. This pathway senses when there is a problem in chromosome attachment. This holds up the cell until you get things right, and then you can progress, and segregate, and distribute your chromosomes. In yeast, that's a nonessential pathway. Those proteins were first identified in budding yeast-beautiful work from Andrew Murray's and Andy Hoyt's labs. They could make null mutants in those and the yeast were fine, but they behaved like they could no longer hold up mitosis when there was a problem. In most papers that are out there, the simplistic statement would be, "Well, these proteins are nonessential in yeast but they're essential in human cells. They're essential in vertebrate cells, so the checkpoint is an essential pathway in human cells."

I don't think that's true. It's true that many of those proteins, if you eliminate them, are essential, but you can create a cell that is genetically checkpoint-defective, and it will grow just fine in culture. That makes you think very differently about what that pathway is, and what its role is. It meets, much more, that classical definition of what a checkpoint is, where it's a pathway that gets activated when there's a problem but that you don't necessarily need it under all circumstances. So many of those proteins are critical for additional roles, but I think the checkpoint itself is not essential.

Lara Szewczak: What was the protein that was the biggest surprise for you? That you thought, "This has to be essential, and it's not."

Iain Cheeseman: Probably, these checkpoint proteins. The ones that we weren't able to eliminate completelyand when I say "we," the person who did this work was Kara McKinley, a graduate student in our lab. Kara made a collection of knockouts where she targeted $>220$ different genes that play roles in cell division. These were things that we would assume would be critical. Maybe $40 \%$ of them didn't show a strong and potent phenotype in cell culture, although we're quite confident that we're getting rid of these things. This complex that we could completely eliminate, which I really thought was going to be central and important, was this Rod-Zw10-Zwilch complex. But you can get rid of those proteins, and the cell is fine.

There've been a lot of other things like that, because it's a question of whether it's a surprise. At the time, it's, "Okay, something's wrong. There should be something happening here. These cell should be dying." But then you start to think about it: "What was the data that made us think that it would be important or essential?" I think that's not only been true with knockouts, but also with specific mutations. I think that there're a lot of things that can compromise a process without killing the cell. The cells are actually pretty robust, and they can tolerate things in cell culture, but some of these low rates of chromosome desegregation, in an organism, would be problematic.

Lara Szewczak: Do you see a pattern? Are things that are more structurally integral more "essential"-whatever that is - than things that are either more peripheral, or that have catalytic activity? Can you categorize your hits that way?

Iain Cheeseman: I continue to be enamored with the kinetochore, but I think one of the features of it that is fascinating is how flexible and plastic it is as a molecular machine.

Lara Szewczak: Do you mean that literally, in terms of deformability, or do you mean in terms of what can be accommodated in a functional unit?

Iain Cheeseman: Literally, it is a structure that can be highly deformed under force and tension, and is very flexible in that way, to be able to resist and handle that force. But mostly, figuratively, in the sense that it is dramatically rewired during evolution. During the cell cycle, it's a dynamic structure: it's assembling and disassembling. I think those answers vary between one organism and the next. I think it's important to define in human cells and in human cell culture what is essential for cell division, what is essential for chromosome segregation, but I think the answer's going to be very different from what that is in budding yeast, or what that is even in mouse cells.

We have a protein that we've worked on where everything that we do to it in human cells seems really central and critical. Then we realized that there was a mouse 
knockout of that, but the mice seemed to grow fine. That really surprised us. I don't think it's so much about a critical catalytic domain or structural role. It's about the way that the human kinetochore has chosen to do that. There are structural proteins that are nonessential in human cells, but those same proteins are structural proteins that are essential in budding yeast. I love that rewiring. It really makes you think. You take something like the ribosome or the proteasome, and these things are largely invariant across eukaryotes. Ribosomes are even pretty similar when you think about the way bacteria do that. And here's this structure that, even over a short evolutionary distance, is changing and adjusting in different ways.

Lara Szewczak: It sounds like you've done this essentiality screen that's opening up a lot. What do you feel is beyond your reach? What's the thing you want to know but you can't quite get there yet?

Iain Cheeseman: That's what keeps you going, right? When I began, we didn't even have the molecular players. There was a historic phase of the field from Fleming through the ' 60 s that was very visual: understanding what the cell division was as a structure, and being able to see the kinetochore early.

The modern molecular age of the kinetochore and cell division began about 1987 when Bill Earnshaw used the CREST autoimmune serum to find some of the first human kinetochore proteins, and there was comparable work in other model organisms. In '97 we still only had a dozen. The number exploded over the next decade. We're largely at that point where we've done the molecular cataloguing, where we know what those parts are. That opens this new door, which is, "Okay, we have all these players. What are they doing?" There's all these activities you need to achieve. How do they work individually and in combination to make that happen? For a lot of the work that we care about, that really is the focus: bringing these together, not thinking about them in isolation, not thinking, "I found this new protein." You have a machine that is an integrated molecular machine. How do you achieve that? I'm really enjoying the stuff that we're playing with for that.

I would also really love to think about how you modulate what this structure is, and how it works in an organismal context. I've been careful about saying "in cell culture." I love human cell culture, and I love our HeLa cells, and, they're a very powerful place to explore things, but what's even more beautiful is to think about the 30 trillion cells in our body: the diversity of tissues and organs, and circumstances and developmental situations, and how you take these core cell biological processes and think about them in an organism. I'm really excited to be able to tackle that. Some of that is starting to be accessible, but there still need to be some better tools.

Lara Szewczak: If there's one tool that you could have to let you ask some new questions, what would it be? What would it let you do?

Iain Cheeseman: For mice to have a 24-hour doubling time, or something like that? Maybe ease our ability to access tissues and control things genetically in mice. There are people who are excellent at that. Our lab needs to learn how to do those. Organoid systems have opened those doors. The tools are there, and they've been developed by diverse labs. There's something that we as a field need to do a better job of taking advantage of, and harnessing. What is the missing reagent? I don't know that there is one. I think that it's possible to make those. Now it's just time to do that.

Lara Szewczak: If you had all your resources at hand and were starting your lab today, brand new, would you ask the same questions, or is there something different that you would go after?

Iain Cheeseman: I teach undergrads cell biology at MIT, and I also love new people coming by our lab. It's really fun for me to talk about these processes and these ideas. I'm surrounded by this unbelievably smart group of people, but most of the questions they ask, my answer is, "I don't know." I love that. As much as we had been able to visually see this structure for a hundred years, the basic things of what it means to be a kinetochore, and what it means to segregate chromosomes and divide a cell (which is such a central biological process): These are things that we simply don't know. I'm so enamored by those ideas and questions that it's like this addiction where, of course, I'd choose to do these again.

I love the physical nature of biology. I love structures. I also love regulatory circuits, and the cell cycle's a nice example of that. I particularly like the interplay between those two. I think that's why I continue to love the kinetochore: because it's a complex and beautiful example of that. You have to achieve this as a very physical thing, but it needs to be intricately controlled and regulated. If it were to be all solved tomorrow, which it's not going to be, I think that there would be other cell biological structures that I would also find fascinating.

Lara Szewczak: Given the stages that the kinetochore has gone through in terms of understanding it, are there lessons there for other large macromolecular dynamic complexes?

Iain Cheeseman: Yeah. In some ways, we're behind some of these. I really love reading about the proteasome and the ribosome. There's excellent work to reconstitute DNA replication in vitro. But we've known about DNA replication for a long time, and many of those factors were identified earlier than kinetochore components and there are still basic questions about them. I think that it did take reconstituting those processes to really understand that. I look at those fields with envy but also to try to learn how we can apply those lessons to whatever this structure is.

I have two excellent DNA replication colleagues in my department: Steve Bell, who has reconstituted many of these things, and Terry Orr-Weaver, who looks at these in a developmental context and trying to understand how different cells and tissues alter the way they're replicating things to create polyploidy or other kinds of amplifications. It's nice to look at those other processes and try to learn from them. I think that there are a lot of parallels for the cilia and the centriole. And there's the nuclear pore, and many other beautiful machines in the cell. 


\section{$\$_{\text {CSH\& }}^{\infty}$ Cold Spring Harbor Symposia SYMPOSIA On Quantitative Biology}

\section{A Conversation with lain Cheeseman}

Cold Spring Harb Symp Quant Biol 2017 82: 378-380 originally published online March 26, 2018 Access the most recent version at doi:10.1101/sqb.2017.82.034454

Creative This article is distributed under the terms of the

Commons http://creativecommons.org/licenses/by-nc/4.0/, which permits reuse and

License redistribution, except for commercial purposes, provided that the original author and source are credited.

Email Alerting Receive free email alerts when new articles cite this article - sign up in Service the box at the top right corner of the article or click here. 